\title{
Determinação da Atividade Antibacteriana do Óleo Essencial de Cymbopogon Flexuosus Contra Staphylococcus Aureus e Pseudomonas Aeruginosa
}

Karine Angélica Dalla Costa (I), Mariane Ferenz (I), Marina Leda Ribeiros (I), Sheila Melo da Silveira (I), Alessandra Farias Millezi (I)

(I) IFC - Instituto Fedral Catarinense - Câmpus Concórdia (Rodovia SC 283 - Km 08 - Vila Fragosos - Concórdia - SC)

\section{Resumo}

A garantia da inocuidade e segurança no processamento de alimentos continua sendo um tema de grande importância. Várias pesquisas vêm sendo desenvolvidas e direcionadas para a investigação de novos agentes antimicrobianos provenientes de extratos de plantas e outros produtos naturais. Os óleos essências (OEs) são produtos voláteis, provenientes do metabolismo secundário de plantas aromáticas, formados em células especiais e encontrados em folhas, flores, sementes, caules e raiz. Apresentam propriedades biológicas diferenciadas, dentre elas a atividade contra microrganismos, sendo de importante interesse para a indústria de alimentos pela possível utilização como princípios ativos de sanitizantes. A atividade antimicrobiana varia de acordo com o óleo utilizado, dos compostos majoritários e do tipo de bactéria. Esta pesquisa objetivou determinar a atividade antimicrobiana do OE obtido das folhas de Cymbopogon flexuosus (capim-limão da Índia Oriental) contra uma bactéria Gram-positiva (Staphylococcus aureus ATCC 29213) e outra Gram-negativa (Pseudomonas aeruginosa ATCC 27853), a fim de iniciar o desenvolvimento de um detergente-sanificante. A eficiência do OE foi detectada pela Concentração Mínima Inibitória (CMI) e Concentração Mínima Bactericida (CMB), através da metodologia de microdiluição. Todos os ensaios foram realizadas em triplicata e em três repetições, os resultados foram expressos em $\mu \mathrm{L} / \mathrm{mL}$. O óleo proporcionou ação contra $\mathrm{S}$. 
aureus, com valores de $\mathrm{CMI}$ e $\mathrm{CMB}$ de $3,9 \mu \mathrm{L} / \mathrm{mL}$ apresentando atividade antimicrobiana satisfatória, devido esta ser a menor concentração testada. Nenhuma das concentrações testadas foi eficiente para inibir P. aeruginosa, então foi realizada a contagem das células da maior concentração $(50 \mu \mathrm{L} / \mathrm{mL})$ em comparação com o controle positivo, no qual obteve-se redução de células viáveis de 1,6 CFU Log $10 \mathrm{~mL}-1$. Os resultados deste estudo demonstram que a atividade antimicrobiana do OE de Cymbopogon flexuosus apresentou efeito somente contra $\mathrm{S}$. aureus.

Palavras-Chave: antimicrobianos naturais, óleos essenciais, bactérias patogênicas, industria de alimentos

Agência de Fomento: Conselho Nacional de Desenvolvimento Científico e Tecnológico (CNPq). 